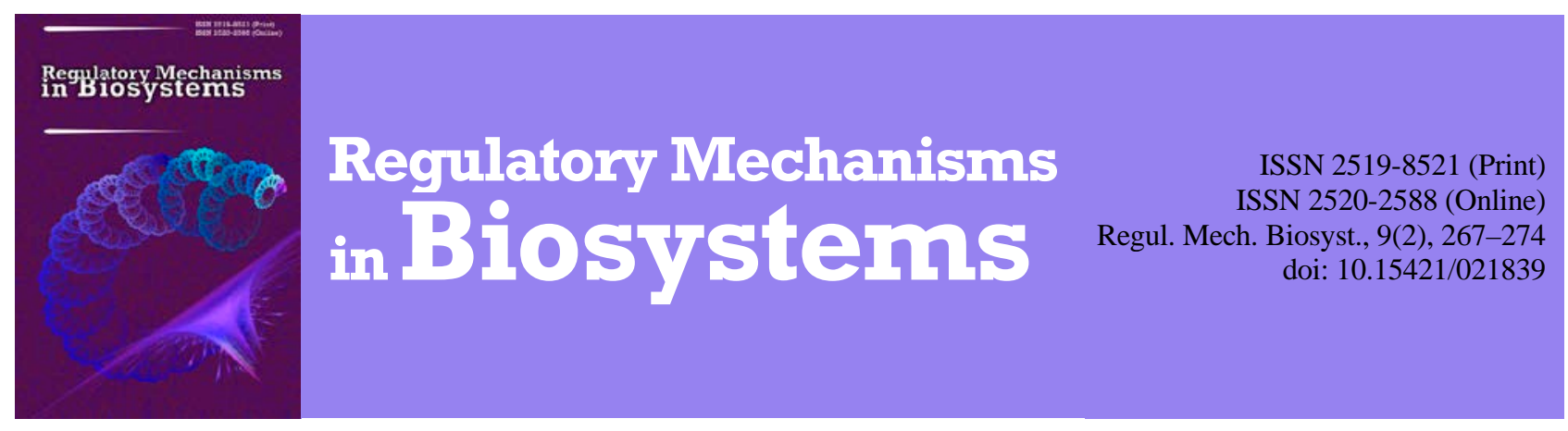

\title{
Regulation of biosynthesis of lipids in Chlorella vulgaris by compounds of zinc, chromium and selenium
}

\author{
O. I. Bodnar, H. B. Kovalska, V. V. Grubinko \\ Volodymyr Hnatiuk Ternopil National Pedagogical University, Ternopil, Ukraine
}

Article info

Received 02.03.2018

Received in revised form 15.04.2018

Accepted 17.04.2018

V. Hnatiuk Ternopil National Pedagogical University,

M. Kryvonosa st., 2,

Ternopil, 46027, Ukraine.

Tel.: +38-097-78-216-98.

E-mail:

bodnar@chem-bio.com.ua
Bodnar, O. I., Kovalska, H. B., \& Grubinko, V. V. (2018). Regulation of biosynthesis of lipids in Chlorella vulgaris by compounds of zinc, chromium and selenium. Regulatory Mechanisms in Biosystems, 9(2), 267-274. doi:10.15421/021839

We studied molecular and metabolic mechanisms of regulated lipid biosynthesis in Chlorella vulgaris aquaculture. after addition of sodium selenite $\left(10 \mathrm{mg} / \mathrm{dm}^{3}\right)$ when added separately and in combination with $\mathrm{Zn}^{2+}\left(5 \mathrm{mg} / \mathrm{dm}^{3}\right)$ and $\mathrm{Cr}^{3+}\left(5 \mathrm{mg} / \mathrm{dm}^{3}\right)$ during 7 days of their action in order to obtain biotechnologically useful lipid products, enriched with microelements. Experiments were carried out in accordance with generally accepted hydrological and biochemical methods. It was established that micronutrients that were added into the medium result in an increase in the total content of lipids in the range of $10 \%$. The redeployment of lipid classes in chlorella cells occurs due to the action of sodium selenite in favour of phospholipids by reducing the proportion of diacylglycerols, while the amount of triacylglycerols and nonetherified fatty acids does not change. Combined action of sodium selenite and zinc ions leads to the significant increase of the relative content of diacylglycerols, and partial increase of nonetherified fatty acids, at the same time in the cells we can observe a slight decrease in the proportion of triacylglycerols and phospholipids. Inclusion of ${ }^{14} \mathrm{C}$-bicarbonate in carbohydrates, proteins and lipids of Ch. vulgaris is significantly different both from the control group and from the group to which we added the investigated factors. However, the predominance of inclusion in lipids is 2-3 times higher than its inclusion into carbohydrates and 9-12 times higher in proteins. The increase of labeled bicarbonate inclusion intensity into carbohydrates occurs only in the case of joint action of sodium selenite and zinc ions, in proteins and lipids - in all cases of trace elemental activity. It was revealed that the general tendency is the reduction of the inclusion of bicarbonate in Ch. vulgaris triacylglycerols and its increase in phospholipids and nonetherified fatty acids, except for chromium ions, that modified the inclusion of the label into diacylglycerols, which may be due to the specific toxicity of the metal ions. The activation of lipogenesis after addition of selenium, zinc and chromium compounds was confirmed by an increase in the inclusion intensity of ${ }^{14} \mathrm{C}$-oleate in various classes of lipids that are present in chlorella and increased activity of glycerol-3-phosphatacyltransferase. Direction and regulation of lipid metabolism in Ch. vulgaris in the direction of increasing the amount and accumulation of lipids and their separate classes using sodium selenite in combination with $\mathrm{Zn}^{2+}$ and $\mathrm{Cr}^{3+}$ with the purpose of forming selenium-metal-lipid complexes can be used to obtain biologically active lipidous preparations enriched with essential microelements.

Keywords: microalgae; micronutrients; lipid metabolism; fatty acids

\section{Регуляція біосинтезу ліпідів у Chlorella vulgaris сполуками цинку, хрому та селену}

\author{
О. І. Боднар, Г. Б. Ковальська, В. В. Грубінко
}

Тернопільський національний педагогічний університет імені Володимира Гнатюка, Тернопіль, Україна

Досліджено молекулярні та метаболічні механізми регульованого біосинтезу ліпідів у Chlorella vulgaris за дії натрій селеніту (10 мг/дм³) окремо та спільно $3 \mathrm{Zn}^{2+}\left(5 \mathrm{mr} /\right.$ дм$\left.^{3}\right)$ i $\mathrm{Cr}^{3+}\left(5,0 \mathrm{mг} /\right.$ дм$\left.^{3}\right)$ упродовж 7 діб їх дії з метою отримання біотехнологічно корисних ліпідних продуктів, збагачених мікроелементами, в умовах аквакультури. Досліди виконували згідно із загальноприйнятими гідрологічними та біохімічними методиками. Внесені в середовище мікроелементи зумовлюють збільшення загального вмісту ліпідів (у межах 10\%). Перерозподіл класів ліпідів у клітинах хлорели відбувається за дії натрію селеніту на користь фосфоліпідів за рахунок зменшення частки діацилгліцеролів, тоді як кількості триацилгліцеролів і неетерифікованих жирних кислот практично не змінюються. За дії натрію селеніту та іонів цинку зростає відносний вміст діацилгліцеролів, неетерифікованих жирних кислот і фосфоліпідів за незначного зниження частки триацилгліцеролів. Спільна дія натрію селеніту та іонів хрому зумовлює суттєве зростання відносного вмісту триацилгліцеролів та частково неетерифікованих жирних

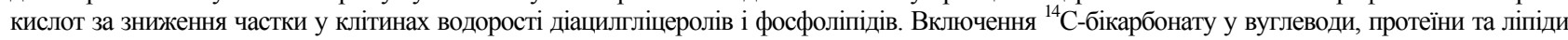
Ch. vulgaris суттєво відрізняється як у контролі, так і за дії досліджених чинників, однак зберігається переважання включення у ліпіди у 2-3 рази відносно інтенсивності включення мітки у вуглеводи та у 9-12 разів - у протеїни. Зростання інтенсивності включення міченого бікарбонату у вуглеводи має місце тільки за спільної дії натрію селеніту та іонів цинку, у протеїни та ліпіди - в усіх випадках мікроелементної дії на клітини водорості. Загальною тенденцією виявилося зниження включення бікарбонату до триацилгліцеролів Ch. vulgaris та його зростання у 
фосфоліпідах і неетерифікованих жирних кислотах, окрім іонів хрому, які модифікували включення мітки до діацилгліцеролів, що може виявитися наслідком специфічної токсикогенності іонів металів. Активація ліпогенезу за дії сполук селену, цинку та хрому підтвердилася здебільшого зростанням інтенсивності включення ${ }^{14} \mathrm{C}$-олеату в різні класи ліпідів клітин хлорели та підвищення активності гліцерол-3фосфатацилтрансферази. Спрямування та регуляція ліпідного метаболізму у Ch. vulgaris у напрямку збільшення кількості та накопичення ліпідів та їх окремих класів за допомогою натрій селеніту спільно $3 \mathrm{Zn}^{2+} \mathrm{Ta} \mathrm{Cr}^{3+}$ із метою утворення селенметалліпідних комплексів можна використати для одержання ліпідних біологічно активних препаратів, збагачених есенційними мікроелементами.

Ключові слова: мікроводорості; мікронутрієнти; ліпідний метаболізм; жирні кислоти

\section{Ветуп}

Природні біологічно активні сполуки, отримані з біомаси водоростей, виступають альтернативою синтетичним компонентам або аналогами інших, із вищою собівартістю виробництва, природних компонентів. Водоростеві субстанції нині мають надзвичайно широке поле до застосування - медицина та фармація (Abd \& El-Baroty, 2013; Agatonovic-Kustrin \& Morton, 2013), діабетологія, харчова промисловість і сільське господарство (Odjadjare et al., 2017), біотехнологія та біоенергетика (Khan et al., 2009; Park et al., 2011), фіторемедіація (Perales et al., 2006; Shalaby, 2011) тощо. Враховуючи велике видове різноманіття наголосимо, що водорості містять значну кількість груп активних органічних компонентів, різної хімічної будови та властивостей. Серед них полісахариди (альгінати, фукоїдан, ламінарин, агар, манан тощо) (Kim, 2013; Park, 2015), пігменти (хлорофіли, фікобіліни, каротиноїди, лютеїн тощо) (El Gamal, 2010; Michalak \& Chojnacka, 2015), ліпіди (насичені жирні кислоти та цінні поліненасичені жирні кислоти $\left(\mathrm{C}_{20: 5, \mathrm{n}-3}\right.$, $\mathrm{C}_{22: 6, \mathrm{n}-3}, \mathrm{C}_{18: 3, \mathrm{n}-6}$ ) (Chen \& Chou, 2002; Haq et al., 2011), бетаїни, поліаміни, стерини, фітогормони (Lu \& Xu, 2015), пептиди та протеїни, поліфеноли та їх похідні (Harnedy \& Fitzgerald, 2011), а також основні вітаміни та мінерали (Croft et al., 2006; Tang \& Suter, 2011). Щодо тварин і людини, то для багатьох цих сполук властивий широкий спектр потенційних лікувально-профілактичний властивостей: антиоксидантні (Fernando et al., 2016; Lukashiv et al., 2016), протиракові, антивірусні, антикоагулянтні, антибактеріальні (Bellou et al., 2014), антиалергічні, антидіабетичні, протизапальні та антигіпертензивні властивості (Lee \& Kim, 2009; Ryu et al., 2014; Kim et al., 2016).

У статті Michalak et al. (2017), яка грунтується на детальному аналізі бази даних Web of Science, показано, що найбільшу наукову увагу з біологічно активних сполук водоростей отримали ліпіди та жирні кислоти, а відтак вони стали одними з найбільш затребуваних для практичного використання водоростевих субстанцій.

Завдяки своїм високим адсорбційним властивостям, водорості здатні поглинати та акумулювати метали та неметали проти градієнта концентрації, завдяки чому мікроелементи накопичуються клітинами та включаються до складу органічних молекул у кількостях, що в рази перевищують їх вміст у середовищі існування (Raja et al., 2008; Richmond \& Hu, 2013).

Сучасні умови життя (несприятлива екологічна ситуація, неадекватне харчування, психоемоційні стреси, шкідливі звички тощо) зумовлюють чималий перелік хронічних захворювань, де на перше місце виходять порушення метаболізму, спричинені інтенсивним утворенням вільних радикалів та підвищенням пероксидних процесів. Тому актуальним і перспективним способом лікування та профілактики порушень обміну речовин може виявитися використання натуральних біологічно активних добавок (БАД) із водоростей, в яких мінеральні речовини природного походження перебувають у зв'язаній формі у природному комплексі $з$ ліпідами. 3 огляду на це, значний інтерес становлять водоростеві комплекси селену та біологічно активних металів цинку та хрому.

Селен - важливий мікроелемент для життедіяльності організму, бо бере участь у клітинному захисті від вільнорадикальних реакцій, незамінний компонент глутатіонової системи, тому корисний для запобігання значної кількості захворювань та їх лікування (Kohrle et al., 2000; Wrobel et al., 2016). Хром (III) поліпшує метаболізм живих організмів, адже він регулює вуглеводний, протеїновий та ліпідний обмін (Vincent, 2013; Brownley et al., 2015; Ganguly et al., 2016). Дослідження показали, що хром необхідний для лікування інсулінорезистентності та цукрового діабету в людей, бо відіграє важливу роль у підтриманні нормального рівня глюкози у крові (Jain et al., 2007; Hua et al., 2012), а також зумовлює зниження рівня холестеролу та триацилгліцеролів у плазмі, пригнічення секреції запальних цитокінів, а в комплексі із селеном - інгібує розвиток оксидативного стресу (Jain et al., 2007; Ganguly et al., 2016). Цинк - один із найголовніших мікроелементів усіх живих організмів, бо необхідний компонент понад 300 ензимів, які контролюють і регулюють протеїновий, ліпідний, вуглеводний і нуклеїновий метаболізм, транскрипцію генів і трансляцію генетичної інформації (Metzler, 2003). Він забезпечує нормальне функціонування репродуктивної системи та репаративні процеси, бере безпосередню участь в імунних реакціях організму. Також цинк - важливий біогенний елемент, що активує енергетичний метаболізм і спрямовує окисно-відновні процеси у клітинах у бік відновних реакцій. Він необхідний для синтезу та утворення гормонів (включно інсуліну), дихальних ензимів (цитохромоксидази), цитохромів $a$ та $b$ i хлорофілу, а відтак забезпечує функціонування клітин у стресових станах і адаптаційних процесах, які потребують підвищення енергоутворення (Metzler, 2003; Kostiuk \& Grubinko, 2012; Maxfield et al., 2018).

Сучасне харчування не забезпечує повноцінного та комплексного надходження багатьох мікроелементів, тому споживання біодобавок може покрити потреби людини в необхідних сполуках (Abd \& El-Baroty, 2013). Щодо хром-, цинк- і селенумісних препаратів, то чимало теперішніх добавок - синтетичні аналоги вітамінів та мінеральних речовин, вони не пов'язані у біологічні комплекси та можуть мати іншу структуру, ніж натуральні нутрієнти, а також вони часто проявляють низьку ефективність і побічні дії. Тому ефективними як джерела селену та інших мікроелементів зарекомендували себе препарати 3 хлорели Ch. vulgaris (Lukashiv et al., 2016), яка стає джерелом біологічно доступних мікроелементів, вітамінів, жирних кислот, ліпідів, хлорофілу, амінокислот тощо (Skrivan et al., 2010; Kim, 2013).

Хлорела - одна з найперспективніших мікроводоростей, яку масово культивують для промислового виробництва нутрицевтиків у формі таблеток або порошку. Перевага використання мікроводоростей для синтезу біоактивних молекул, у тому, що ïх можна вирощувати на великомасштабному виробництві з регульованими фізико-хімічними параметрами. Тому оптимальне співвідношення мікроелементів, які вносяться у середовище культивування, наперед може визначати спрямування біохімічних реакцій і перебудову як загального метаболізму, так і ліпідного, що дає змогу ефективно та безпечно включати метали та неметали у ліпіди з метою отримання біотехнологічно корисних продуктів в умовах аквакультури.

Мета цього дослідження - 3'ясувати молекулярні та метаболічні механізми регульованого біосинтезу ліпідів у Chlorella vulgaris, ліпідний склад водоростей, інтенсивність включення ${ }^{14} \mathrm{C}$ бікарбонату в органічні сполуки та ${ }^{14} \mathrm{C}$-олеату в ліпіди різних класів за дії натрій селеніту $\left(10,0 \mathrm{мг} /\right.$ дм $\left.^{3}\right)$ окремо та спільно 3 $\mathrm{Zn}^{2+}\left(5,0 \mathrm{мг} /\right.$ дм$\left.^{3}\right)$ i з $\mathrm{Cr}^{3+}\left(5,0 \mathrm{мг} /\right.$ дм$\left.^{3}\right)$ упродовж 7 діб їх дії.

\section{Матеріал і методи досліджень}

Об'єкт дослідження - альгологічно чиста культура зеленої водорості Chlorella vulgaris Beij. ССАР-211/11в, отримана із колекцій Інституту гідробіології НАН України. Водорость культивували на середовищі Фітцджеральда в модифікації Цендера та Горхема № 11, за температури $22-25{ }^{\circ} \mathrm{C}$ та освітлення лампами 
денного світла (інтенсивність 2500 Лк) упродовж 16 год. на добу (Romanenko, 2004). В умовах експерименту до культури водоростей додавали водний розчин селеніту натрію $\left(\mathrm{Na}_{2} \mathrm{SeO}_{3}\right)$ у розрахунку на кількість Se(IV) - 10,0 мг/дм ${ }^{3}$ та водні розчини $\mathrm{ZnSO}_{4} \cdot 5 \mathrm{H}_{2} \mathrm{O}$ та $\mathrm{CrCl}_{3} \cdot 6 \mathrm{H}_{2} \mathrm{O}$ у розрахунку на вміст $\mathrm{Zn}^{2+} \mathrm{i} \mathrm{Cr}^{3+}-$ по 5,0 мг/дм ${ }^{3}$ (Lutsiv \& Grubinko, 2012). Контролем слугувала культура, яку вирощували у середовищі без додавання натрію селеніту, солей хрому і цинку. Біомасу живих клітин відбирали на сьому добу культивування (Skrivan et al., 2010).

Включення ${ }^{14} \mathrm{C}$-бікарбонату у протеїни, вуглеводи, ліпіди та ліпіди різних класів $\mathrm{i}^{14} \mathrm{C}$-олеату у ліпіди різних класів досліджували шляхом інкубації суспензії хлорели відповідно з 20 кБк бікарбонатом натрію $\left(\mathrm{NaH}_{14} \mathrm{CO}_{3}\right)$ та 3184 кБк ${ }^{14} \mathrm{C}$-олеатом $\left(\mathrm{C}_{17} \mathrm{H}_{33} \mathrm{COOH}\right)$ за температури $20-22^{\circ} \mathrm{C}$ і освітленні 2500 лк протягом 90 хв (Lutsiv \& Grubinko, 2012; Yang et al., 2015). Після зупинення реакції трихлороцтовою кислотою здійснювали екстракцію протеїнів, вуглеводів та ліпідів. Радіоактивність зразків вимірювали на сцинтиляційному лічильнику LS-100C «Beckman» (США). Для визначення загальної кількості вуглеводів у біомасі водоростей, їх осаджували трихлороцтовою кислотою, далі екстрагували розчином $75 \%$ етанолу, після чого центрифугували, двічі промивали, знову осаджували центрифугуванням, висушували до постійної ваги, зважували, та здійснювали авторадіографування отриманих зразків (Molecular-genetic and biochemical methods, 2012).

Визначення загального вмісту протеїнів у біомасі водоростей здійснювали через їх осадження $5 \%$ розчином трихлороцтової кислоти та центрифугуванням, далі осад розчиняли в етанолі та знову центрифугували, після чого його промивали сумішшю етанол : диетиловий ефір $(3: 1)$ та підсушували ефіром. Протеїни солюбілізували $5 \mathrm{M} \mathrm{KOН} \mathrm{за} 70^{\circ} \mathrm{C}$ протягом 24 год, нейтралізували, висушували та зважували та визначали їх радіоактивність (Vovk \& Yanovich, 1988).

Для біохімічного дослідження ліпіди екстрагували хлороформ-метаноловою сумішшю у відношенні $2: 1$ методом Фолча (Hokin \& Hexum, 1992). При цьому до однієї масової частки вологої біомаси додавали 20 масових часток екстрагувальної суміші та залишали на 12 годин для екстракції ліпідів. Неліпідні домішки 3 екстракту видаляли відмиванням $1 \%$ розчином $\mathrm{KCl}$ (Prokhorova, 1982; Stefanyk et al., 1985). Кількість загальних ліпідів визначали ваговим методом після відгонки екстрагувальної суміші, висушували у термостаті та зважували.

Розділення ліпідів на окремі фракції здійснювали методом висхідної одномірної тонкошарової хроматографії в герметич- них камерах на пластинках із сумішшю силікагелів ЛС 5/40 $\mu$ і Л $5 / 40 \mu$ на скляній основі. Перед початком роботи пластинки активували протягом 30 хв за $105^{\circ} \mathrm{C}$ у сушильній шафі, обробляли $10 \%$ спиртовим розчином фосфорномолібденової кислоти та висушували їх у потоці теплого повітря упродовж 10-15 хвилин. Хлороформний розчин проби ліпідів наносили на пластинку мікродозатором у кількості, яка не перевищувала 200 мкг ліпідів, після чого повільно поміщали пластинки у хроматографічні камери. Рухомою фазою слугувала суміш гексану, диетилового ефіру та льодяної оцтової $(70: 30: 1)$. Одержані хроматограми проявляли в камері, насиченій парами йоду, для ідентифікації окремих фракцій ліпідів використовували специфічні реагенти та очищені стандарти. У процесі роботи виявлено такі класи ліпідів: фосфоліпіди, діацилгліцероли, триацилгліцероли та неетерифіковані жирні кислоти (Stefanyk et al., 1985).

Кількість неполярних ліпідів визначали за допомогою біхроматного методу (Prokhorova, 1982) - до проби ліпідів додавали $1 \mathrm{~N}$ розчин біхромату калію та концентровану сульфатну кислоту. Ліпіди у досліджуваних зразках спалювали за температури $160-180{ }^{\circ} \mathrm{C}$. Вимірювали інтенсивність забарвлення на спектрофотометрі СФ-46 за довжини хвилі 615 нм. Визначали вміст окремих класів ліпідів за калібрувальною кривою. Вміст фосфоліпідів визначали методом Васьковського: за температури $180{ }^{\circ} \mathrm{C}$ концентрованою хлорною кислотою проводили мінералізацію фосфоліпідів, а оптичну густину розчину визначали за допомогою спектрофотометра (Stefanik, 1985; Vaskovsky et al., 1985).

Активність гліцерол-3-фосфатацилтрансферази (КФ 2.3.1.15) визначали за Yang et al. (2015). Вихідну суспензію водорості розтирали у фарфоровій посудині та інкубували у скляних колбах за $20{ }^{\circ} \mathrm{C}$ та освітлення 2500 лк із 184 кБк ${ }^{14} \mathrm{C}$-олеатом $\left(\mathrm{C}_{17} \mathrm{H}_{33} \mathrm{COOH}\right)$ iз 0,6 мМ гліцерол-3-фосфатом, тритоном X-100, $2 \mathrm{MM} \mathrm{MgCl} 2$ протягом 60 хвилин. Реакцію зупиняли додаванням $10 \%$ трихлороцтової кислоти. Далі центрифугували та з отриманого осаду екстрагували ліпіди методом Нічолса в модифікації (Stefanyk et al., 1985; Lutsiv \& Grubinko, 2012). Отримані зразки авторадіографували. Одержані експериментальні дані опрацьовані методами варіаційної статистики за допомогою програми Statistica 6.0 (StatSoft Inc., USA).

\section{Результати}

Внесені у середовище мікроелементи зумовлюють часткову перебудову ліпідного метаболізму, насамперед змінюють вміст ліпідів різних класів (табл. 1).

\section{Таблиця 1}

Кількість загальних ліпідів в аліквоті культури Ch. vulgaris і вміст ліпідів різних класів у них за дії натрій селеніту (10,0 мг $\mathrm{Se}(\mathrm{IV}) /$ дм$^{3}$ ) окремо та спільно $3 \mathrm{Zn}^{2+}$ i $\mathrm{Cr}^{3+}-$ по 5,0 мг/дм ${ }^{3}$ (мг, 7 діб, $\mathrm{M} \pm \mathrm{m}, \mathrm{n}=5$ )

\begin{tabular}{|c|c|c|c|c|c|}
\hline $\begin{array}{c}\text { Варіанти досліду } \\
\text { з мікроелементами }\end{array}$ & $\begin{array}{c}\text { Загальна } \\
\text { кількість ліпідів }\end{array}$ & Триацилгліцероли & Діацилгліцероли & $\begin{array}{c}\text { Неетерифіковані } \\
\text { жирні кислоти }\end{array}$ & Фосфоліпіди \\
\hline Контроль & $7,74 \pm 0,41$ & $1,65 \pm 0,40$ & $1,01 \pm 0,16$ & $0,99 \pm 0,08^{*}$ & $4,10 \pm 0,38$ \\
\hline Se(IV) & $8,38 \pm 0,51$ & $1,68 \pm 0,23$ & $0,83 \pm 0,04 *$ & $0,97 \pm 0,04 *$ & $4,91 \pm 0,34$ \\
\hline $\mathrm{Se}(\mathrm{IV})+\mathrm{Zn}^{2+}$ & $8,79 \pm 1,22$ & $1,56 \pm 0,13^{*}$ & $1,31 \pm 0,28$ & $1,47 \pm 0,12^{*}$ & $4,45 \pm 0,26^{*}$ \\
\hline $\mathrm{Se}(\mathrm{IV})+\mathrm{Cr}^{3+}$ & $8,51 \pm 0,41 *$ & $2,91 \pm 0,13^{* *}$ & $0,86 \pm 0,03^{*}$ & $1,19 \pm 0,04 * *$ & $3,54 \pm 0,12 *$ \\
\hline
\end{tabular}

Примітка: * - $\mathrm{P}<0,10, * *-\mathrm{P}<0,05$, різниця вірогідна порівняно з контролем.

За впливу натрію селеніту окремо та за спільної дії з іонами цинку та іонами хрому загальний вміст ліпідів у клітинах Ch. vulgaris зростає на 8,9\%, 13,6\% та 10,1\%, відповідно. При цьому в експериментальних системах практично не змінюється щодо контролю вміст триацилгліцеролів за дії селеніту окремо та спільно із цинком, тоді як за спільної дії із хромом кількість триацилгліцеролів у хлорели збільшується на 76,4\%. Щодо вмісту діацилгліцеролів у клітинах водорості, тут виявлені такі зміни: за впливу натрію селеніту окремо їх кількість зменшується на 17,8\%, за спільної його дії з іонами цинку вміст діацилгліцеролів зростає щодо контролю на 29,7\%, а за спільної дії селеніту та хрому - знижується на 14,9\%. Зазнає змін також вміст фосфоліпідів у Ch. vulgaris: за впливу натрію селеніту окремо та спільної його дії з іонами цинку їх вміст відповідно зростає на
19,8\% та 9,5\% щодо контролю, а за спільної дії селеніту та хрому знижується на 13,7\%. Відповідно до виявлених тенденцій змінюється вміст неетерифікованих жирних кислот: за впливу натрію селеніту спільно 3 іонами цинку та 3 іонами хрому зростає, відповідно, на 48,5\% та 20,2\% порівняно з контрольними показниками, а за дії селеніту окремо практично не відрізняється від величини контролю.

Для оцінювання інтенсивності метаболізму загалом та ліпогенезу зокрема ми дослідили включення ${ }^{14} \mathrm{C}$-бікарбонату в органічні сполуки клітин Ch. vulgaris (рис. 1).

Включення ${ }^{14} \mathrm{C}$-бікарбонату у вуглеводи, протеїни та ліпіди Ch. vulgaris суттєво відрізняється як у контролі, так і за дії досліджених чинників, однак зберігається переважання включення у ліпіди у 2-3 рази відносно інтенсивності включення мітки у 
вуглеводи. Включення мітки у протеїни теж виявилося меншим у 9-12 разів відносно інтенсивності включення мітки в ліпіди за дії всіх досліджуваних мікроелементів. За культивування водорості у середовищі 3 мікроелементами цей процес інтенсифікується. Якщо тенденція до зростання включення міченого бікарбонату у вуглеводи має місце тільки за спільної дії натрію селеніту та 3 іонами цинку, то процес включення міченого бікарбо-

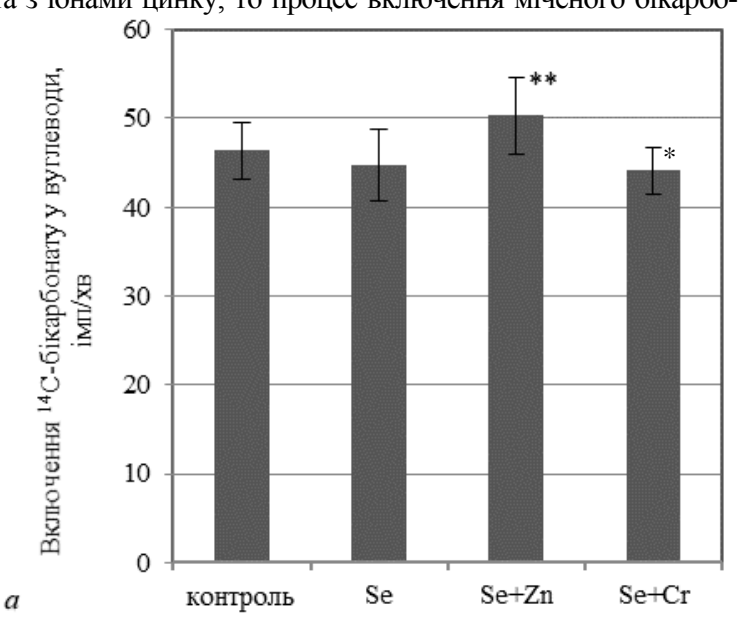

нату у протеїни активно відбувається в усіх випадках мікроелементної дії. Стосовно ліпідів водорості, у цьому випадку інтенсивність включення ${ }^{14} \mathrm{C}$-бікарбонату достовірно стимулює всі використані суміші іонів: натрій селеніт окремо активує включення на $29,7 \%$, спільно $з$ іонами цинку - на $37,0 \%$, а 3 іонами хрому - на 35,6\% щодо контролю. Дія іонів металів на фоні селеніту посилює інтенсивність процесу на 9,2\% для обох металів.

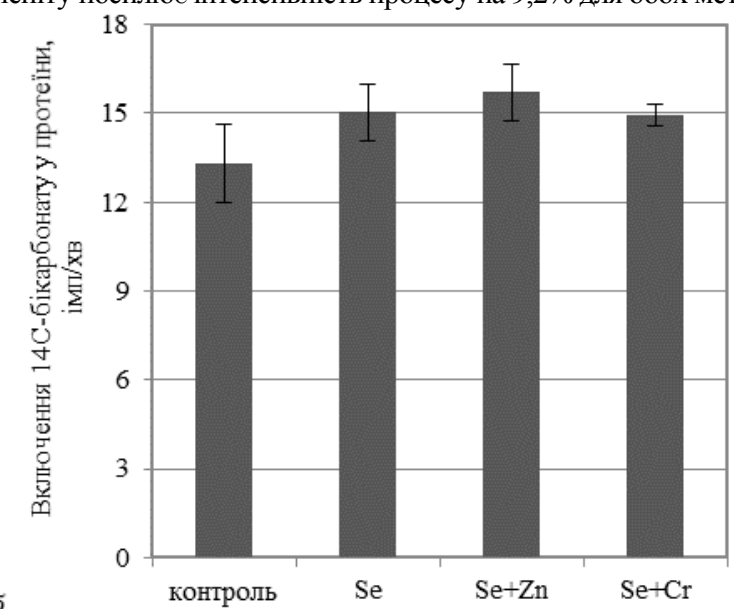

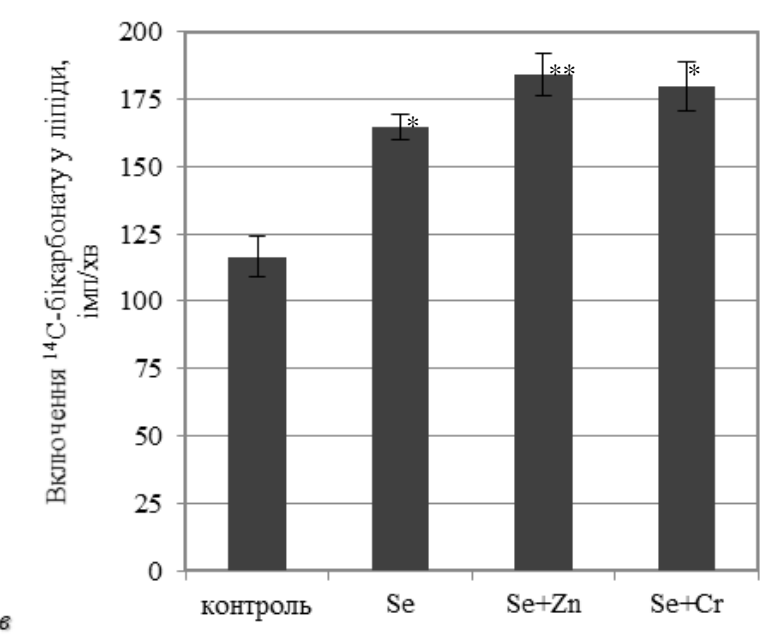

Рис. 1. Інтенсивність включення ${ }^{14} \mathrm{C}$-бікарбонату в органічні сполуки клітин Ch. vulgaris за дії натрій селеніту $\left(10,0\right.$ мг Se(IV)/дм $\left.{ }^{3}\right)$ окремо та спільно із $\mathrm{Zn}^{2+} \mathrm{i} \mathrm{Cr}^{3+}-$ по 5,0 мг/дм ${ }^{3}$, імп./хв· мг сухої маси, $\mathrm{M} \pm \mathrm{m}, \mathrm{n}=3$ : $a$ - вуглеводи; $\sigma$ - протеїни; 6 - ліпіди; * $-\mathrm{P}<0,10$, ** - $\mathrm{P}<0,05$ різниця вірогідна порівняно 3 контролем

У зв'язку з виявленим ефектом становить інтерес дослідження включення ${ }^{14} \mathrm{C}$-бікарбонату до складу окремих класів ліпідів клітин Ch. vulgaris (табл. 2).

\section{Таблиця 2}

Інтенсивність включення ${ }^{14} \mathrm{C}$-бікарбонату в окремі класи ліпідів у Ch. vulgaris за дії натрій селеніту $\left(10,0\right.$ мг Se(IV)/дм³ ${ }^{3}$ окремо та спільно $3 \mathrm{Zn}^{2+} \mathrm{i} \mathrm{Cr}^{3+}-$ по 5,0 мг/дм ${ }^{3}$ (імп./хв• мг сухої маси ліпідів, $\mathrm{M} \pm \mathrm{m}, \mathrm{n}=5$ )

\begin{tabular}{lcccc}
\hline $\begin{array}{c}\text { Варіанти } \\
\text { досліду 3 } \\
\text { мікроеле- } \\
\text { ментами }\end{array}$ & $\begin{array}{c}\text { Триацил- } \\
\text { гліцероли }\end{array}$ & $\begin{array}{c}\text { Діацил- } \\
\text { гліцероли }\end{array}$ & $\begin{array}{c}\text { Неетерифі- } \\
\text { ковані жирні } \\
\text { кислоти }\end{array}$ & Фосфоліпіди \\
\hline Контроль & $86,38 \pm 5,41$ & $68,21 \pm 1,86$ & $14,49 \pm 0,45$ & $69,85 \pm 3,21$ \\
$\mathrm{Se}(\mathrm{IV})$ & $88,11 \pm 7,09$ & $68,09 \pm 3,28$ & $15,89 \pm 0,09 *$ & $87,82 \pm 5,11^{*}$ \\
$\mathrm{Se}(\mathrm{IV})+\mathrm{Zn}^{2+}$ & $70,64 \pm 4,47 *$ & $55,21 \pm 3,76^{*}$ & $20,58 \pm 1,12^{* *}$ & $72,89 \pm 3,11$ \\
$\mathrm{Se}(\mathrm{IV})+\mathrm{Cr}^{3+}$ & $44,47 \pm 1,87 * * *$ & $93,59 \pm 7,24 *$ & $21,07 \pm 1,25 * *$ & $71,58 \pm 1,37 * *$ \\
\hline Примітка: * $-\mathrm{P}<0,10, * *$ \\
порівняно 3 контролем.
\end{tabular}

У контролі максимальне включення мітки спостерігаємо в триацилгліцероли, рівною мірою в діацилгліцероли та фосфоліпіди, практично уп'ятеро менше в неетерифіковані жирні кислоти. В усіх варіантах дії мікроелементів на клітини Ch. vulgaris загаль- на тенденція щодо включення ${ }^{14} \mathrm{C}$-бікарбонату в різні класи ліпідів зберігається, однак знижується частка ії включення у триацилгліцероли, особливо за спільної дії натрію селеніту та іонів хрому (на 48,5\%). Разом із тим, інтенсивність включення мітки в діацилгліцероли порівняно 3 контрольними показниками за дії селеніту окремо практично не змінюється, за спільної дії селеніту іонами цинку дещо зменшується (на 19,1\%), але значно зростає (на $37,2 \%$ ) за спільної дії натрію селеніту та іонів хрому. Щодо включення міченого бікарбонату в неетерифіковані жирні кислоти, то за дії селеніту окремо порівняно з контролем інтенсивність збільшується лише на 9,7\%, тоді як, за спільної присутності селеніту 3 іонами цинку та селеніту з іонами хрому інтенсивність включення міченого елемента зростає відповідно на $42,0 \%$ та $45,4 \%$ в обох випадках. Інтенсивність включення ${ }^{14} \mathrm{C}$-бікарбонату у фосфоліпіди хлорели порівняно з контролем має тенденцію до збільшення в усіх досліджуваних варіантах досліду: за дії селеніту окремо - на $25,8 \%$, за спільної дії селеніту із цинком і селеніту з хромом - до $5 \%$.

Активація ліпогенезу за дії сполук селену, цинку та хрому підтвердилася здебільшого зростанням інтенсивності включення ${ }^{14} \mathrm{C}$-олеату в різні класи ліпідів клітин хлорели та підвищення активності гліцерол-3-фосфатацилтрансферази - одного 3 ключових ензимів біосинтезу ліпідів (рис. 2, 3), активність якого оцінювали за включенням у ліпіди ${ }^{14} \mathrm{C}$-олеату. 


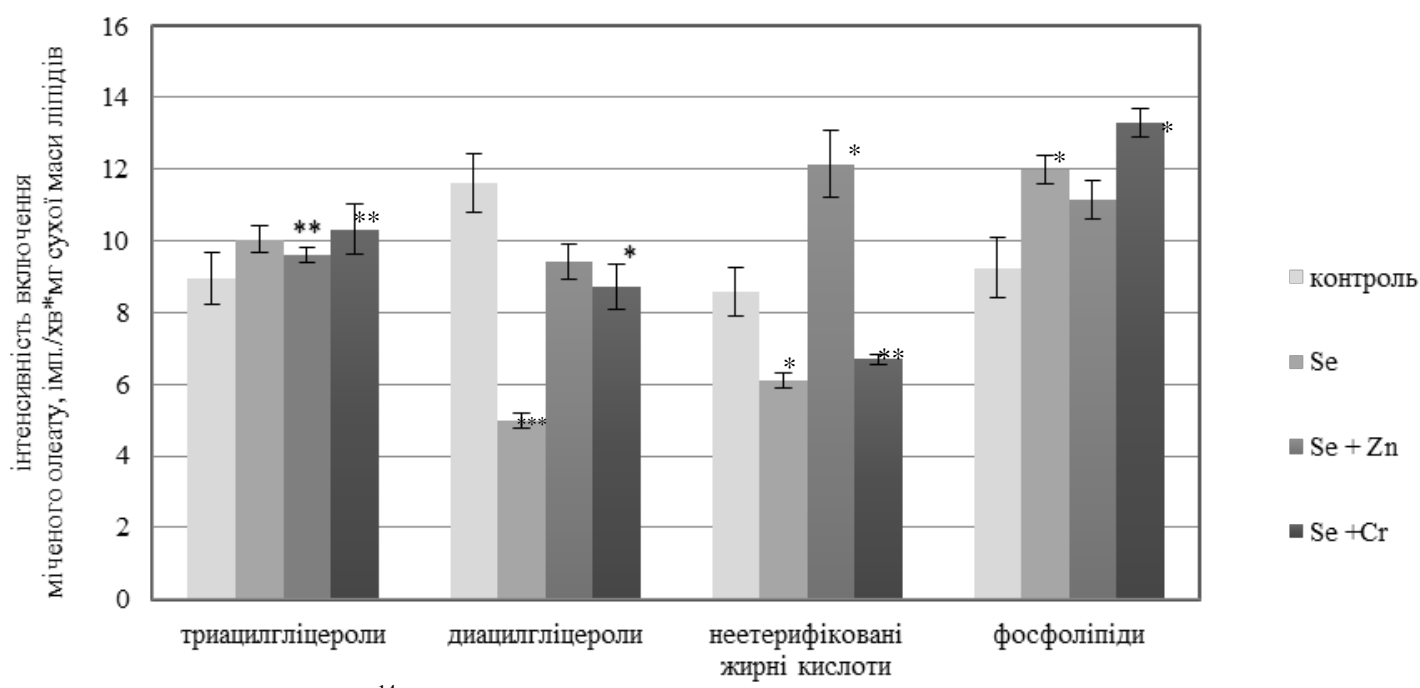

Pис. 2. Інтенсивність включення ${ }^{14} \mathrm{C}$-олеату у Ch. vulgaris у ліпіди різних класів за дії натрій селеніту $\left(10,0\right.$ мг Se(IV)/дм $\left.{ }^{3}\right)$ окремо та спільно з $\mathrm{Zn}^{2+}$ i $\mathrm{Cr}^{3+}$ - по 5,0 мг/дм³ ${ }^{3}$, імп./хв• мг сухої маси ліпідів $(\mathrm{M} \pm \mathrm{m}, \mathrm{n}=5)$ :

$*_{-} \mathrm{P}<0,10,{ }^{* *}-\mathrm{P}<0,05, * * *-\mathrm{P}<0,001$, різниця вірогідна порівняно $з$ контролем

Інтенсивність включення ${ }^{14} \mathrm{C}$-олеату до складу триацилгліцеролів Ch. vulgaris вища порівняно з контролем на $11,9 \%$ за дії селеніту окремо, на 7,1\% - за спільної дії селеніту та цинку та на 15,2\% - за спільної дії селеніту та хрому. Аналогічний процес спостерігали щодо фосфоліпідів: інтенсивність включення міченого олеату більша, ніж у контролі, на $29,6 \%, 20,8 \%$ та $43,9 \%$ відповідно за дії селеніту окремо, спільної дії селеніту з цинку та селеніту із хромом. Однак використання ${ }^{14} \mathrm{C}$-олеату у процесі утворення діацилгліцеролів у клітинах водорості зменшується за дії всіх мікроелементів. При цьому за дії лише селеніту зміни виявилися помітнішими (на 57,1\% менше контролю), ніж за дії селеніту з металами: на 18,9\% менше за дії з цинком та на 24,9\% менше за дії із хромом.

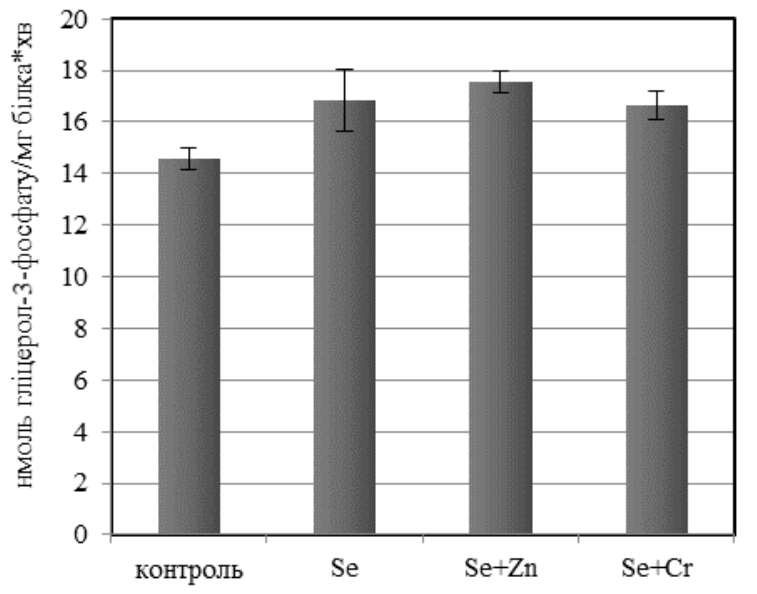

Рис. 3. Активність гліцерол-З-фосфатацилтрансферази у Ch. vulgaris за дії натрій селеніту (10,0 мг Se(IV)/дм $\left.{ }^{3}\right)$ окремо та спільно із $\mathrm{Zn}^{2+} \mathrm{i} \mathrm{Cr}^{3+}-$ по 5,0 мг/дм ${ }^{3}$ (нмоль Г-З-Ф/мг білка· хв,

$\mathrm{M} \pm \mathrm{m}, \mathrm{n}=5)$ : * $-\mathrm{P}<0,10$, різниця вірогідна порівняно з контролем

Щодо неетерифікованих жирних кислот, то дія селеніту окремо та селеніту із хромом зумовлює зменшення процесу включення міченого олеату до їх складу відповідно на 28,8\% та 22,0\% порівняно $з$ показниками контролю, тоді як за спільної дії селеніту та цинку має місце підвищення інтенсивності включення мітки на 41,5\% відносно контролю.

Щодо реакційної здатності ензиму гліцерол-3-фосфатацилтрансферази у хлорели, яка регулює синтез діацилгіцеролів, а відтак і триацилгліцеролів, то в усіх варіантах досліду має місце зростання іiі активності. За впливу селеніту окремо ії активність збільшується на 15,4\% порівняно 3 контролем, а на фоні додат- кової мікроелементної дії активність Г-З-ФАТ більша на 20,3\% за впливу із цинком і на $14,1 \%$ - за впливу із хромом відносно контрольної величини.

\section{Обговорення}

Загальною тенденцією впливу досліджуваних мікроелементів виявилися чіткі кількісні та якісні зміни вмісту окремих класів ліпідів у клітинах Ch. vulgaris. Перерозподіл класів ліпідів у клітинах хлорели відбувається за дії натрію селеніту на користь фосфоліпідів за рахунок зменшення частки діацилгліцеролів, тоді як кількість триацилгліцеролів і нетерифікованих жирних кислот практично не змінюються. За дії натрію селеніту та іонів цинку зростає відносний вміст діацилгліцеролів, нетерифікованих жирних кислот і фосфоліпідів за незначного зниження частки триацилгліцеролів. Спільна дія натрію селеніту та іонів хрому зумовлює суттєве зростання відносного вмісту триацилгліцеролів і частково нетерифікованих жирних кислот за зниження частки у клітинах водорості діацилгліцеролів і фосфоліпідів.

Підвищення вмісту фосфоліпідів у клітинах хлорели узгоджується 3 даними про його зростання за стресових ситуацій (Chirkova, 1997; Rozentsvet et al., 2005), i, очевидно, пояснюється тим, що ці ліпіди одні з чинників зміни плинності мембран за фізико-хімічних змін клітинного оточення (Kostyuk \& Grubinko, 2012). Збільшенням вмісту діацилгліцеролів і неетерифікованих жирних кислот пояснюється активацією ліпаз за стресової дії факторів середовища (Schmid \& Ohlrogge, 2002; Richmond \& Hu, 2013). Іони хрому, ймовірно, здійснюють перебудову метаболізму ліпідів на користь триацилгліцеролів як наслідок адаптивної стабілізації мембран для запобігання проникнення цього токсиканту у клітини.

Відмічене зниження включення бікарбонату до триацилгліцеролів Ch. vulgaris та його зростання у фосфоліпідах і нетерифікованих жирних кислотах за дії мікроелементів, окрім іонів хрому, які модифікували включення мітки до діацилгліцеролів, може виявитися наслідком специфічної токсикогенності іонів важких металів (Rozentsvet et al., 2005; Chia et al., 2013; Chen et al., 2017).

Включення міченого олеату до складу триацилгліцеролів свідчить про зростання їх біосинтезу, а також має місце зниження біосинтезу діацилгліцеролів і тенденція до зростання біосинтезу фосфоліпідів у всіх випадках дії мікроелементів щодо контролю. Включення мітки олеату в нетерифіковані жирні кислоти наслідок зміни пулу жирних кислот, пов'язаний з активацією ліпідного метаболізму за дії солей селену, цинку та хрому. Вищі жирні кислоти - одні 3 найлабільніших компонентів клітин водоростей, їх склад забезпечує первинну відповідь і адаптивні реакції організму та може змінюватися залежно від умов середови- 
ща (Schmid \& Ohlrogge, 2002; Kelly et al., 2016). Біосинтез ліпідів у рослин, у тому числі й у водоростей, локалізований переважно у пластидах (Schmid \& Ohlrogge, 2002; Chen et al., 2017). Синтез більшості вільних жирних кислот de поvо відбувається у хлоропластах, цитозоль клітин рослин, на відміну від тваринних організмів, у синтезі жирних кислот участі не бере. У ньому функціонує система модифікації ацильного ланцюга синтезованих у пластидах жирних кислот, що транспортуються на ендоплазматичний ретикулюм завдяки ацилтрансферазам, утворюючи при цьому жирні кислоти, що використовуються у біосинтезі восків і запасних ліпідів (Dormann, 2007), тобто переважно адаптивних форм ліпідів. Олеат виступає попередником і складовою частиною багатьох жирних кислот, які включаються до складу гліцероліпідів (Metzler, 2003). Щодо основного компонента клітинних мембран - фосфоліпідів, зростання інтенсивності включення ${ }^{14} \mathrm{C}$-олеату свідчить про активацію мембранних процесів $\mathrm{i}$ формування токсикорезистентності клітин водорості до дії досліджуваних мікроелементів. Виявлена закономірність співвідноситься 3 результатами щодо збільшення кількості ліпідів (табл. 1) і фактом активного ліпогенезу у хлорели (Harwood \& Guschina, 2009; Widjaja et al., 2009).

За включення олеату активується гліцерол-З-фосфатацилтрансфераза - перший мембранозв'язаний ензим, що ініціює процес біосинтезу триацилгліцеролів шляхом Кеннеді при передаванні ацильної групи від ацил-КоА або ацил-АПБ (в пластидах) в $\mathrm{s}_{\mathrm{n}-1}$ або $\mathrm{s}_{\mathrm{n}-2}$ положення гліцерол-3-фосфату (Wang et al., 2004). Гліцерол-3-фосфатацилтрансфераза володіє високою специфічністю до субстрату, особливо до залишку мононенасиченої олеїнової кислоти як донора ацильної групи (Turnbull et al., 2001). Синтезовані продукти, очевидно, вступають у подальші реакції біосинтезу окремих класів ліпідів (триацилгліцеролів і фосфоліпідів), про що свідчить досить висока активність гліцерол-3-фосфатацилтрансферази та тенденція до ії зростання за впливу мікроелементів. Цей факт співвідноситься 3 підтриманням клітинами стаціонарного вмісту триацилгліцеролів і фосфоліпідів у клітинах хлорели. Висока активність гліцерол-3-фосфатацилтрансфераз також пов'язана 3 формуванням адаптивних відповідей, насамперед, зі зростанням вмісту у клітинних мембранах окремих (адаптивних) класів ліпідів (Kostyuk \& Grubinko, 2012; Lutsiv \& Grubinko, 2012). Ліпідний склад клітин за дії стресових чинників значно змінюється, а за адаптації гідробіонтів до екстремальних чинників середовища в клітинах змінюється не тільки співвідношення окремих класів ліпідів, а і їх жирнокислотний склад (Morash et al., 2009; Lv Jian et al., 2010; Chia et al., 2013). Дослідження Kostyuk \& Grubinko (2012) свідчать про компенсаторно-адаптивні зміни в мембранах водних рослин, у тому числі Chlorella vulgaris, за дії чинників середовища існування. Один із важливих механізмів модифікації ліпідного метаболізму - біосинтез фосфоліпідів (Krebs, 1981).

Загальний механізм формування токсикорезистентності у водних рослин до дії чинників супроводжується зростанням кількості фосфоліпідів, бо саме їх вміст впливає не тільки на плинність мембран, а i на формування мікросередовища для мембранних ензимів, іонних каналів, а також даний підклас ліпідів регулює зв'язок клітин із зовнішнім середовищем (Abbas \& Card, 1980). Інтенсивність цього процесу можлива завдяки високій сорбційній здатності заряджених фосфоліпідів (Wang et al., 2004), або ж виконанням ними функції месенджерів, які передають інформацію всередину клітини про зміни навколишнього середовища (Vigh et al., 1988). Первинними компенсаторними відповідями на стрес чи зміни фізико-хімічних параметрів середовища вирощування виступають зміни ступеня ненасиченості жирних кислот фосфоліпідів, що може порушувати плинність мембрани або інші ії фізичні характеристики (Schmid \& Ohlrogge, 2002; Wang et al., 2004; Rozetsvet et al., 2005).

Щодо перерозподілу вмісту та біосинтезу ліпідів інших класів, такі зміни розвиваються повільніше. Підвищення вмісту триацилгліцеролів - один із чинників стабілізації клітинних мембран (Lewis \& McElhaney, 2000) з одночасним процесом ущіль- нення та зменшення їх плинності (Dyatlovitskaya \& Bezuglov, 1998). Оскільки триацилгліцероли - основний запасний енергетичний субстрат, збільшення їх вмісту свідчить про підвищення енергетичних потреб, що виникають у результаті дії змін навколишнього середовища. Для того, щоб забезпечити клітину необхідним енергетичним матеріалом, активується ліполіз, а рівень триацилгліцеролів після початкового підвищення їх вмісту зменшується.

\section{Висновки}

Дослідження показало можливість регуляції метаболізму в бік посилення біосинтетичних процесів в одноклітинної зеленої водорості Ch. vulgaris в умовах аквакультури з метою отримання елементліпідних сполук - перспективних фармацевтичних препаратів комплексного типу. За дії мікроелементів Se (IV) у концентрації $\left(10 \mathrm{мг} / \mathrm{дm}^{3}\right)$ окремо та спільно $3 \mathrm{Zn}^{2+}\left(5 \mathrm{mr} / \mathrm{дm}^{3}\right) \mathrm{i} \mathrm{Cr}^{3+}$ $\left(5 \mathrm{Mr} /\right.$ дм $\left.^{3}\right)$ упродовж 7 діб мало місце збільшення загальної кількості ліпідів до 13\% порівняно з контролем. Перерозподіл класів ліпідів у клітинах хлорели відбувається за дії натрію селеніту на користь фосфоліпідів за рахунок зменшення частки діацилгліцеролів, тоді як кількість триацилгліцеролів і нетерифікованих жирних кислот практично не змінюються. За дії натрію селеніту та іонів цинку зростає відносний вміст діацилгліцеролів, нетерифікованих жирних кислот і фосфоліпідів за незначного зниження частки триацилгліцеролів. Спільна дія натрію селеніту та іонів хрому зумовлює суттєве зростання відносного вмісту триацилгліцеролів та частково нетерифікованих жирних кислот за зниження частки у клітинах водорості діацилгліцеролів і фосфоліпідів. Включення ${ }^{14} \mathrm{C}$-бікарбонату у Ch. vulgaris відбувається у 2-3 рази інтенсивніше в ліпіди, ніж у вуглеводи, та у 9 12 разів - ніж у протеїни за всіх варіантів досліду. Зростання інтенсивності включення міченого бікарбонату у вуглеводи має місце тільки за спільної дії натрію селеніту та іонів цинку, у протеїни та ліпіди - в усіх випадках мікроелементної дії.

Загальна тенденція - зниження включення бікарбонату до триацилгліцеролів Ch. vulgaris та його зростання у фосфоліпідах і нетерифікованих жирних кислотах. Активація ліпогенезу за дії сполук селену, цинку та хрому підтвердилася здебільшого зростанням інтенсивності включення ${ }^{14} \mathrm{C}$-олеату в різні класи ліпідів клітин хлорели та підвищення активності гліцерол-3-фосфатацилтрансферази. Спрямування та регуляція ліпідного метаболізму Ch. vulgaris у напрямку збільшення кількості та накопичення ліпідів та їх окремих класів за допомогою натрій селеніту спільно $з$ $\mathrm{Zn}^{2+}$ та $\mathrm{Cr}^{3+} 3$ метою утворення селенметалліпідних комплексів можна використати для одержання ліпідних біологічно активних препаратів, збагачених есенційними мікроелементами.

\section{References}

Abbas, C. A., \& Card, G. L. (1980). The relationship between growth temperature, fatty acid composition and the physical state and fluidity of membrane lipids in Yersinia enterocolitica. Biochimica et Biophysica Acta, 602(3), 469-476.

Abd, E. B., \& El-Baroty, G. S. (2013). Healthy benefit of microalgal bioactive substances. Journal of Aquatic Science, 1(1), 11-23.

Agatonovic-Kustrin, S., \& Morton, D. W. (2013). Cosmeceuticals derived from bioactive substances found in marine algae. Oceanography, 1(2), 106.

Bellou, S., Baeshen, M. N., Elazzazy, A. M., Aggeli, D., Sayegh, F., \& Aggelis, G. (2014). Microalgal lipids biochemistry and biotechnological perspectives. Biotechnology Advances, 32(8), 1476-1493.

Brownley, K. A., Boettiger, C. A., Young, L. A., \& Cefalu, W. T. (2015). Dietary chromium supplementation for targeted treatment of diabetes patients with comorbid depression and binge eating. Medical Hypotheses, 85(1), 45-48.

Chen, B., Wan, C., Mehmood, M. A., Chang, J.-S., Bai, F., \& Zhao, X. (2017) Manipulating environmental stresses and stress tolerance of microalgae for enhanced production of lipids and value-added products: Review. Bioresource Technology, 244, 1198-1206.

Chen, C. Y., \& Chou, H. N. (2002). Screening of red algae filaments as a potential alternative source of eicosapentaenoic acid. Marine Biotechnology, 4(2), 189-192.

Chia, M. A., Lombardi, A. T., Gracë, M., Melro, G., \& Parrish, C. C. (2013) Lipid composition of Chlorella vulgaris (Trebouxiophyceae) as a function 
of different cadmium and phosphate concentrations. Aquatic Toxicology, 128-129, 171-182.

Chirkova, T. V. (1997). Kletochnye membrany i ustoychivost rasteniy k stresssovym vozdeystviyam [Cell membranes and plant resistance to stress effects]. Soros Journal of Education, 9, 12-17 (in Russian).

Croft, M. T., Warren, M. J., \& Smith, A. G. (2006). Algae need their vitamins. Eukaryotic Cell, 5(8), 1175-1183.

Dörmann, P. (2007). Lipid synthesis, metabolism and transport. In: R. R. Wise, \& J. K. Hoober (Eds.). The structure and function of plastids. Springer, Dordrecht (Netherlands). Pp. 335-353.

Dyatlovitskaya, E. V., \& Bezuglov, V. V. (1998). Lipidy kak bioeffektory [Lipids as bioeffectors]. Biochemistry, 63(1), 3-5 (in Russian).

El Gamal, A. A. (2010). Biological importance of marine algae. Saudi Pharmaceutical Journal, 18(1), 1-25.

Fernando, I. P., Kim, M., Son, K. T., Jeong, Y., \& Jeon, Y. J. (2016). Antioxidant activity of marine algal polyphenolic compounds: A mechanistic approach. Journal of Medicinal Food, 19(7), 615-628.

Ganguly, R., Wen, A. M., Myer, A. B., Czech, T., Sahu, S., Steinmetz, N. F., \& Raman, P. (2016). Anti-atherogenic effect of trivalent chromium-loaded CPMV nanoparticles in human aortic smooth muscle cells under hyperglycemic conditions in vitro. Nanoscale, 8(12), 6542-6554.

Haq, I., Muhammad, A., \& Hameed, U. (2014). Comparative assessment of Cladophora, Spirogyra and Oedogonium biomass for the production of fatty acid methyl esters. Applied Biochemistry and Microbiology, 50(1), 69-72.

Harnedy, P. A., \& FitzGerald, R. J. (2011). Bioactive proteins, peptides, and amino acids from macroalgae. Journal Phycology, 47(2), 218-232.

Harwood, J. L., \& Guschina, I. A. (2009). The versatility of algae and their lipid metabolism. Biochimie, 91(6), 679-684.

Hokin, L. E., \& Hexum, T. D. (1972). Studies on the characterization of the sodium - potassium transport adenosine triphosphatase: IX on the role of phospholipids in the enzyme. Archives of Biochemistry and Biophysics, 151(2), 453-463.

Hua, Y., Clark, S., Ren, J., \& Sreejayan, N. (2012). Molecular mechanisms of chromium in alleviating insulin resistance. The Journal of Nutritional Biochemistry, 23(4), 313-319.

Jain, S. K., Rains, J. L., \& Croad, J. L. (2007). High glucose and ketosis (acetoacetate) increases, and chromium niacinate decreases, IL-6, IL-8, and MCP-1 secretion and oxidative stress in U937 monocytes. Antioxidants and Redox Signaling, 9, 1581-1590.

Kelly, A. A., Kalisch, B., Hölzl, G., Schulze, S., Thiele, J., Melzer, M., Dörmann, P. (2016). Synthesis and transfer of galactolipids in the chloroplast envelope membranes of Arabidopsis thaliana. Proceeding of the National Academy Science USA, 113(38), 10714-10719.

Khan, S. A., Rashmi, H., Mir, Z., Prasad, S., \& Banerjee, U. C. (2009). Prospects of biodiesel production from microalgae in India. Renewable and Sustainable Energy Reviews, 13, 2361-2372.

Kim, S. K. (2013). Marine nutraceuticals: Prospects and perspectives. CRC Press, Boca Raton.

Kim, S., Kim, J., Lim, Y., Kim, Y. J., Kim, J. Y., \& Kwon, O. (2016). A dietary cholesterol challenge study to assess Chlorella supplementation in maintaining healthy lipid levels in adults: A double-blinded, randomized, placebo controlled study. Nutrition Journal, 15, 54.

Köhrle, J., Brigelius-Flohé, R., Böck, A., Gärtner, R., Meyer, O., \& Flohé, L. (2000). Selenium in biology: Facts and medical perspectives. Biological Chemistry, 381(9-10), 849-864.

Kostiuk, K. V., \& Grubinko, V. V. (2012). Change of composition of the cellular membranes of the aquatic plants under the impact of toxic substances. Hydrobiological Journal, 48(4), 75-92.

Kreps, E. M. (1981). Lipidy kletochnyih membrane [Lipids of cell membranes]. Science, Leningrad (in Russian).

Kuznetsov, V. V., Kuznetsov, V. V., \& Romanov, G. A. (Eds.). (2012). Molekulyarno-geneticheskie i biohimicheskie metody v sovremennoy biologii rasteniy [Molecular-genetic and biochemical methods in modern plant biology]. Binom, Moscow (in Russian).

Lee, H. S., \& Kim, M. K. (2009). Effect of Chlorella vulgaris on glucose metabolism in Wistar rats fed high fat diet. Journal of Medicinal Food, 12(5), 1029-1037.

Lewis, R. N. A. H., \& McElhaney, R. N. (2000). Surface charge markedly attenuates the nonlamellar phase-forming properties of lipid bilayer membranes: Calorimetric and ${ }^{31} \mathrm{P}$-nuclear magnetic resonance studies of mixtures of cationic, anionic, and zwitterionic lipids. Biophysical Journal, 79(3), 1455-1464.

Lu, Y., \& Xu, J. (2015). Phytohormones in microalgae: A new opportunity for microalgal biotechnology? Trends in Plant Science, 20(5), 273-282.

Lukashiv, O. Y., Bodnar, O. I., Vinyarska, H. B., \& Grubinko, V. V. (2016). Vplyv selen-khrom-lipidnoii substantsii iz Chlorella vulgaris Biej. na oksydatyvnyi status shchuriv [Effect of selenium-chromium-lipid substance on
Chlorella vulgaris Biej. the oxidative status of rats]. Medical and Clinical Chemistry, 18(2), 28-33 (in Ukrainian).

Lutsiv, A. I., \& Grubinko, V. V. (2012). Localization of the lipids' synthesis in Chlorella vulgaris under the impact of lead and zinc ions and diesel fuel. Hydrobiological Journal, 48(6), 95-106.

Lv, J.-M., Cheng, L.-H., Xu, X.-H., Zhang, L., \& Chen, H.-L. (2010). Enhanced lipid production of Chlorella vulgaris by adjustment of cultivation conditions. Bioresource Technology, 101, 6797-6804.

Metzler, D. (2003). Biochemistry: The chemical reactions of living cells. Academic Press, New York-London.

Michalak, I., \& Chojnacka, K. (2015). Algae as production systems of bioactive compounds. Engineering in Life Science, 15(2), 160-176.

Michalak, I., Chojnacka, K., \& Saeid, A. (2017). Plant growth biostimulants, dietary feed supplements and cosmetics formulated with supercritical $\mathrm{CO}_{2}$ algal extracts. Molecules, 22(1), 66.

Morash, A. J., Bureau, D. P., \& McClelland, G. B. (2009). Effects of dietary fatty acid composition on the regulation of carnitine palmitoyltransferase (CPT)I in rainbow trout (Oncorhynchus mykiss). Comparative Biochemistry and Physiology. Part B: Biochemistry and Molecular Biology, 152(1), 85-93.

Odjadjare, E. C., Mutanda, T., \& Olaniran, A. O. (2017). Potential biotechnological application of microalgae: A critical review. Critical Reviews in Biotechnology, 37(1), 37-52.

Park, J. B., Craggs, R. J., \& Shilton, A. N. (2011). Wastewater treatment high rate algal ponds for biofuel production. Bioresource Technolology, 102(1), 35-42.

Park, J. K. (2015). Algal polysaccharides: Properties and applications. Biochemistry and Analytical Biochemistry, 4, 176.

Perales-Vela, H. V., Pena-Castro, J. M., \& Canizares-Villanueva, R. O. (2006). Heavy metal detoxification in eukaryotic microalgae. Chemosphere, 64, 1-10.

Prokhorova, M. I. (Ed.). (1982). Metody biokhimicheskikh issledovaniji (lipidnyji i energeticheskiji obmen) [Methods of biochemical studies (lipid and energy metabolism)]. Leningrad University Press, Leningrad (in Russian).

Raja, R., Hemaiswarya, S., Kumar, N. A., Sridhar, S., \& Rengasamy, R. A. (2008). Perspective on the biotechnological potential of microalgae. Critical Reviews in Microbiology, 34(2), 77-88.

Richmond, A., \& Hu, Q. (Eds.). (2013). Handbook of microalgal culture: Applied phycology and biotechnology. John Wiley \& Sons Ltd., Oxford.

Romanenko, V. D. (Ed.). (2004). Osnovy gidroekologii [Fundamentals of hydroecology]. Geneza, Kyiv (in Ukrainian).

Rozentsvet, O. A., Murzaeva, S. V., \& Gushchina, I. A. (2005). Rol' membrannyh lipidov v ustoychivosti Potamogeton perfoliatus L. k izbyitku kadmiya v vode [The role of membrane lipids in the resistance of Potamogeton perfoliatus L. to excess of cadmium in water]. Biology Bulletin, 32(2), 232-239 (in Russian).

Ryu, N., Lim, Y., Park, J. E., Kim, J., Kim, J. E., Kwon, S. W., \& Kwon, O. (2014). Impact of daily Chlorella consumption on serum lipid and carotenoid profiles in mildly hypercholesterolemic adults: A double-blinded, randomized, placebo-controlled study. Nutrition Journal, 13(1), 57.

Schmid, K. M., \& Ohlrogge, J. B. (2008). Lipid metabolism in plants. In: D. E. Vance \& J. E. Vance (Eds.). Biochemistry of lipids, lipoproteins and membranes. Elsevier Science B.V. Pp. 98-130.

Shalaby, E. A. (2011). Algae as promising organisms for environment and health. Plant Signaling Behavior, 6(9), 1338-1350.

Skrivan, M., Skrivanova, V., Dlouha, G., Branyikova, I., Zachleder, V., \& Vitova, M. (2010). The use of selenium-enriched alga Scenedesmus quadriccauda in chicken diet. Czech Journal Animal Science, 55(12), 565-571.

Stefanik, M. B., Skorokhid, V. I., \& Eliseeva, O. P. (1985). Tonkoslojinaya i gazozhydkostnaya chromatografiya lipidov [Thin-layer and gas-liquid chromatography of lipids]. LGU, Lvov (in Russian).

Tang, G., \& Suter, P. M. (2011). Vitamin A, nutrition, and health values of algae: Spirulina, Chlorella and Dunaliella. Journal of Pharmacy and Nutrition Sciences, 1, 111-118.

Turnbull, A. P., Rafferty, J. B., Sedelnikova, S. E., Slabas, A. R., Schierer, T. P., Kroon, J. T., Rice, D. W. (2001). Analysis of the structure, substrate specificity, and mechanism of squash glycerol-3-phosphate (1)-acyltransferase. Structure, 9, 347-353.

Vaskovsky, V. E., Kostetsky, E. V., \& Vasendin I. M. (1985). A universal reagent for phospholipids analysis. Joumal of Chromatography, 114(1), 129-141.

Vigh, L., Horvath, I., \& Thompson, G. A. (1988). Recovery of Dunaliella salina cells following hydrogenation of lipids in specific membranes by a homogeneous palladium catalyst. Biochimica et Biophysica Acta (BBA)Biomembranes, 937(1), 42-50.

Vincent, J. B. (2013). Chromium: Is it essential, pharmacologically relevant, or toxic? Metal Ions Life Sciences, 13, 171-198.

Vovk, S. I., \& Yanovich, V. G. (1988). Issledovanie sinteza belkov v tkanyakh selskokhozaistvennykh zhivotnykh (metodicheskie recomendatsii) [Investigation of protein synthesis in tissues of agricultural animals (guidelines)]. Unii, Lvov (in Russian). 
Wang, L., Zhou, Q., \& Chua, H. (2004). Contribution of cell outer membrane and inner membrane to $\mathrm{Cu}^{2+}$ adsorption by cell envelope of Pseudomonas putida 5-x. Journal of Environmental Science and Health Part A, 39(8), 2071-2080.

Widjaja, A., Chien, C.-C., \& Ju, Y.-H. (2009). Study of increasing lipid production from fresh water microalgae Chlorella vulgaris. Journal of the Taiwan Institute of Chemical Engineers 40(1), 13-20.
Wrobel, J. K., Power, R., \& Toborek, M. (2016). Biological activity of selenium: Revisited. IUBMB Life, 68(2), 97-105.

Yang, J., Cao, J., Xing, G., \& Yuan, H. (2015). Lipid production combined with biosorption and bioaccumulation of cadmium, copper, manganese and zinc by oleaginous microalgae Chlorella minutissima UTEX2341. Bioresource Technology, 175, 537-544. 